OLEKSANDRA BIBIK,

Vasyl Stus Donetsk National University (Vinnytsia, Ukraine)

e-mail:aleks.7.pad@gmail.com,ORCID0000-0002-6610-852X

\title{
TRANSFORMATION OF THE JAPANESE MEMORY POLITIC IN THE II HALF OF XX-XXI CENTURIES IN THE CONTEXTS OF PAN-ASIAN AMBITIONS
}

\begin{abstract}
The article is devoted to the analyses of the role of Pan-Asianism in the formation of the Japanese policy of memory in the period after World War II. Since the Meiji period, Japan has had a dual relationship with Asia: on the one hand, as a region of high spirituality and culture, on the other, as a region lagging behind the West or Europe in terms of economic, political and technological development. In the 1950s, when Japan was experiencing a period of economic crisis caused by the defeat of the war, the occupation regime, and the formation of military memory, we see a trend of Japanese intellectuals classifying Japan as "Asia". If during World War I Pan-Asian ideology was used to correct imperial ideology and colonialism, modern Pan-Asian concepts tend to create a union of Southeast Asian countries for support and mutual development. The further development of these sentiments depends on the implementation of existing ASEAN projects and the specifics of the adopted political and economic strategies of the Asian Commonwealth.

The articles provide the first comprehensive analysis of the constitutional documents, editions and speeches of Japanese politicians, which show the transformations of Japanese memory politic. The main terms of development of this policy, which consist in patient orientation and gradual formation of new Asianism, are separated. Discussions around Yasukuni-jinja and Japanese history textbooks as examples of these trends in Japanese politics are analyzed.

Provided that Japan's pacifist position is enshrined in the constitution, there are conservative and nationalist views on the Japanese war in Asia. As part of Japan's policy of remembrance, PanAsianism fosters an ambivalent attitude toward Japanese expansion in Asia. Subject to Japan's official admission of guilt to neighbouring countries, condemnation of expansionism and colonialism, and the transition to pacifism, there are conservative and nationalist views on the Japanese war in Asia. Within the conservative position, Japanese guilt is questioned and the need to recognize the heroic participants in the war is proclaimed, the "Great East Asian War" is interpreted as a war of self-defence, or the correctness and truth of Pan-Asian ideals of Taisho and Showa Japan are recognized.
\end{abstract}

Key word: Pan-Asianism, memory politic, New Asianism, Yasukuni Shrine.

Introduction

Since the Meiji Revolution, Pan-Asianism has spread to the fields of economy, political ideology, as well as to culture and religion. After the end of World War II, PanAsianism as an ideology of imperialism ceased to be relevant. But the idea of the need to unite Asia is beginning to operate and spread in the fields of foreign policy and international relations. The study of these ideas, their origins and consequences of implementation will help to understand the vectors of the current Japanese strategy for the development of relations with the countries of East Asia.

After the defeat of Japan in World War II, PanAsianism was condemned as a hostile ideology of imperialism and colonial policy. The revival of the very ideas of Asian unity can be considered in 1947 when the First International Conference on Asian Relations was held in Delhi. The conference condemned pre-war Pan-Asianism for its similarity to Western colonialism and discussed several issues related to the protest against Western colonization of Asia (Takenaka, 2015, 43-44).

ISSN 1728-9343 (Print)

ISSN 2411-3093 (Online)
The discussion on these issues was continued during a conference in Bandung in 1955, where the so-called Non-Aligned Movement was formed. The conference focused on finding ways to resolve international global conflicts and protesting against Anglo-American world hegemony. As a result of the conference, several decisions on economic development were made and 10 principles of peaceful coexistence were discussed.

Regarding cultural interaction was made the following conclusion: "The cultures of Asia and Africa are based on universal principles and spirituality. Unfortunately, contact between Asia and Africa has been cut off over the centuries. Now the peoples of Asia and Africa are inspired by a common desire to restore their ancient cultures and develop new ones in the context of the modern world" (Final Communique ..., 1955). This is how the expansion and rethinking of the format of inter-Asian and Asian-African relations are formed. At the same time, the pan-Asian idea of the Asian commonwealth and the need to unite Asian countries that share a common spiritual and cultural foundation continue to live on. Against the background

SKHID Vol. 1 (2) May-June 2021 
of these trends, this period also develops a competitive to the Pan-Asian - Pan-Pacific vector of Asian relations (Kapranov 2015: 51-52). In post-war Japan, a key moment in the formation and resumption of the search for national identity that began in the Meiji period was the reassessment of attitudes toward both Pan-Asianism and Asia itself. Characteristically, at this time the problem of conflict between Western (as progressive) and Asian (as traditional, but backward from the West) identities arises again. An important point of such reflection and reassessment of one's own identity is the statement of the Japanese sociologist Shimizu Ikutaro (清水幾太郎, 19071988) from 1950: "And now, let's repeat: the Japanese are Asians" (Duus, 2001). At the same time, in the rhetoric of the Japanese Communist Party positioned itself as a semi-colonized Asian state.

\section{Methods}

The politics of memory is understood as the methods by which a new discourse of society's view of certain events of the past is formed. Japanese memory politics is characterized by an ambivalent attitude toward PanAsianism as a phenomenon that coexisted with Japanese expansionism and imperialism. On the other hand, it is the political dimensions of building an ambivalent attitude to the history of the late XIX - the first half of the XX century. Cause a tense situation in the East Asian region as a whole. Analysing the connection between modern memory politics and the phenomenon of Japanese PanAsianism will help to better understand not only PanAsianism itself, but also its future perspectives and current manifestations.

\section{Result and Discussions}

S. Saaller emphasizes the connection between PanAsianism and modern Japanese politics of memory. For example, the researcher notes an ambiguous assessment of the Fifteen Years' War in Japan: while Japan's aggression against other Asian countries is officially recognized, some views describe this period as an era of Japan's war for the liberation of Asia or as a defensive war. Thus, Pan-Asian rhetoric is used by right-wing nationalists and modern sympathetic ideologies of imperialism. Analysing the work of the Prime Minister of Japan Abe Shinzo (安倍晋三, 1954) "Towards a Beautiful Country" (「美 Lい国へ」) from 2006, S. Saaller emphasizes the influence of these sentiments on the formation of modern politics. memory (Takenaka, 2015). The policy of memory as a policy of preventing the mention of Pan-Asianism in any of its forms is analysed by E. Hotta, K. Fujiwara, Y. Takatori. In this case, the study of memory policy focuses on Japan's efforts to avoid mentioning the Fifteen Years' War in socio-political discourse, along with Japan's image as a modernized peaceful country.

The project of the East Asian community and the forms of the revival of Pan-Asianism in the period after World War II are considered in detail in the works of S.V. Kapranov. Works such as "China in the Ideology of Japanese Pan-Asianism" (Kapranov, 2017) and "The East Asian Community Project and China's Place in It: the Japanese Perspective" (Kapranov, 2015) analyse contemporary concepts of Asian solidarity, political programs and philosophical ideas based on Pan-Asian principles. Based on the data and discourse of the study of the role of modern Pan-Asianism in building inter-Asian relations, the main purpose of our article we see the analysis of the place and role of Pan-Asian ambitions and their implementation in the formation of Japanese memory policy in the second half of XX - XXI centuries.

At present, there are two directions in Japan's policy of remembrance for the events of 1930-1945: the first focuses on pacifism as the main focus of post-war peaceful Japan, the second focuses on the contradictory moments of recent Japanese history and the danger of a resurgence of militarism in the country. While the first direction is key to Japan's soft power policy in the context of creating a positive image of the country, the second direction creates the danger of international conflicts and leads to criticism of Japan by countries involved in the Pan-Asian dialogue. Let's analyse the history of formation and features of implementation in modern Japan in both directions.

Analysing the peculiarities of the formation of one's view of the military events of the first half of the $X X$ century. and defeat in war, Hashimoto Akiko (橋本明子) in his monograph Long Defeat: Cultural Trauma, Memory, and Identity in Japan shows that Japan's search for a new political culture is based on the experience of dealing with the national trauma of military defeat. The researcher distinguishes three possible ways to solve the situation of ambivalent attitude to wars in general: nationalism, pacifism and reconciliation (Hashimoto 2015). Pacifism as a basis for identity formation is the active promotion of anti-war sentiment and anti-nuclear policy (Hatoyama, 2009). According to the official position of the Japanese government, enshrined in Article 9 of the Constitution, modern Japan is a pacifist state.

At the same time, the nationalist path is to overcome the negative experience of the past and gradually form the image of a strong Japan. For example, former Japanese Prime Minister Abe Shinzo speaks of "eliminating the post-war regime" and building a "new and beautiful" Japan (Kuan-hsin, 2010). In particular, in 2014, Abe proposed to revise the ninth article of the constitution on the country's military force, strengthen national self-defence and form a "positive pacifism" in Japanese politics. As a result, the amendment "Constitution and the right of self-defence" (憲 法と自衛権 - "kenpo: to jieiken") ${ }^{1}$ was adopted, which approved the following three positions on the conditions of Japan's use of military force:

1. In the event of a military offensive against Japan or a country closely connected with Japan, which would jeopardize the existence of the country and the right of its citizens to life, liberty and happiness;

2. If there are no means other than military to resolve the conflict and overcome the threat;

3. Military action must be limited to "the use of the minimum necessary force" ${ }^{2}$.

The third option is to form a view of the military events of the first half of the XX century. is to recognize Japan's defeat in the war as real, to survive the past, and to build a modern identity based on the principles of regional integration. The difficulty of defining the discourse of

\footnotetext{
${ }^{1}$ Kenpō to jiei. Bōei-shō no seisaku.

https://www.mod.go.jp/j/approach/agenda/kihon02.html. (In Japanese)

${ }_{2}$ lbid.
} 
memory politics is explained by the presence of all three positions in the context of modern Japanese politics.

The formation of an ambivalent policy of memory, in particular, was facilitated by the soft policy of the American occupation of Japan (1945-1952), during which Emperor Hirohito (裕仁; Emperor Sowa - 昭和天皇; 19011989) was not recognized. guilty of Japan's war (and vice versa, according to the decision of the occupying power, assisted in rebuilding the country). Class-A war criminals were given lenient sentences that did not involve the death penalty. Researchers of the Japanese politics of memory S. Lawson and Tanaka Seiko call these facts key to the formation of a dual attitude to the "Great East Asian War" (大 大亜戦 争 - "daito:a senso:") by Japanese citizens and representatives of political elites (Mahathir, 1994). Based on these facts, H.P. Bix in his monograph "Military Responsibility and Historical Memory: The Hirohito Phenomenon" concludes that it is this policy of the occupying forces that lead to the belief in the moral justification of Japan's actions in Asia - that is, to the belief that "the great East Asian war "was fought for the liberation of the Far East from European imperialism (Bix, 2001). Despite the lack of agreement among researchers to assess the role of Pan-Asianism in the Japanese strategy of the first half of the twentieth century, at the official level Pan-Asianism is considered a justification for Japanese military aggression in Asia and a means of political propaganda. At the same time, it should be noted that the belief in the justice of Pan-Asian ideals continues to be maintained at the level of the general public.

One of the contentious issues that still cause conflicts between Japan and East Asia on suspicion of not only imperialist sentiments in Japan but also people who sympathize with such sentiments, is the Yasukuni Shrine ( 靖国神社 - "yasukuni jinja") ${ }^{3}$. Characteristically, the sanctuary is supported by followers of the nationalist position and the strategy of softening the view of the Asian war. Yasukuni-jinja is a place of preservation of lists of soldiers who died defending Japan. A cornerstone in the sanctuary's history, which draws the attention of political elites and the international community to it, is the fact that 14 Japanese figures of the Showa and Taisho eras, convicted of surrendering as war criminals, are revered in Yasukuni-jinja as "eirei" (英霊) (Takenaka, 2016). Another issue that draws attention to the Yasukuni Shrine is the intendants of periodic visits (which are periodically characterized as pilgrimages) to the shrine by representatives of the Japanese authorities.

Since December 13, 2001, then-Prime Minister Koizumi Junichiro (小泉 純 一郎, 1942) has visited the Yasukuni Shrine six times, prompting criticism from the international community. For example, in 2005, Koizumi's repeated visits to the Yasukuni Jinja led to meetings with the Deputy Prime Minister of the State Council of China (I, 1938). In response to the allegations, at a press conference in 2005, Koizumi Junichiro gave the following answer about the reason for the pilgrimage to the Yasukuni Shrine: "I, Prime Minister Koizumi Junichiro, make a pilgrimage to the Yasukuni Shrine as a representative of the Japanese nation. Japan's peace and prosperity are shaped not only by those who live now. We

\footnotetext{
${ }^{3}$ Sanpai no shiori. Yasukunijinja. https://www.yasukuni.or.jp/assets/pdf/precincts/map/yasuku ni shiori ja.pdf. (In Japanese)
}

ISSN 1728-9343 (Print)

ISSN 2411-3093 (Online) must not forget that today's peace has been achieved through those who have lost their precious lives on the battlefield. I visit the Yasukuni Shrine to express my condolences to the spirits of those killed in the war. Besides, Japan should never go to war again. We remember that which is why Japan has not been at war for the last 60 years" (Koizumi sōri-daijin naigai kisha kaiken, (2005). The Prime Minister also noted that he visits the Yasukuni Shrine alone, unaccompanied by colleagues from parliament. Several times in the speech it was emphasized that Japan is not currently waging wars, but only organizing humanitarian support to countries that need it.

Then, on December 26, 2013, Japanese Prime Minister Abe Shinzo paid an official visit to Yasukuni-jinja, which also provoked a backlash and criticism among the people and political elites of China, South Korea, the United States and Russia. Despite the marked international reaction, the shrine was also visited by other Japanese officials in 2014. In addition, 146 deputies are visiting the shrine on April 22. This tradition continues in 2015 when 70 deputies of the Japanese Parliament come to the sanctuary on an official visit. The lists of official visits of representatives of the Japanese parliament to Yasukuni-jinja can be extended. In response to the criticism of these visits, there is a tendency to focus on the private nature of each pilgrimage.

It should be noted the dual attitude to the sanctuary in the middle of Japan itself: on the one hand, it is morally correct to form respect for the past, on the other hand, Yasukuni is considered a symbol of Japanese militarism and colonial policy of the Japanese Empire. Researchers of Japanese politics in memory of A. Inuzuka and T. Fuch conclude that the sanctuary is indirect propaganda of Japanese militarism and a source of new national memory of the Asia-Pacific War as a war of self-defence. Some studies also conclude that militaristic sentiment is on the rise in modern Japan. In A. Takenov's work, the policy towards Yasukuni-jinja is considered as a case of using the method of post-memory as a means to form an idealized image of the past (Tankha, 2003). S. Koji examines the double issue of criticism of the politics of memory concerning the Yasukuni shrine and the fact of the legislative separation of religion from politics, enshrined in the Japanese constitution of 1947 (Fretwell, 2016).

In response to the aggravated political situation around the sanctuary, the official website of Yasukuni-jinja tried to justify Japan's actions during the war of 1930-1945. in the Fifteen Years' War to create a "Sphere of Common Prosperity" for all Asian countries.

In addition, in the official pamphlet "Information for pilgrims. The purpose of founding and operating the sanctuary is as follows: "The purpose of the sanctuary of Yasukuni is to worship precious spirits equally - those people who died in the struggle for the homeland, regardless of their gender, merit or social status. This is necessary to comfort the spirits of those who gave their lives for the homeland and to talk about them to future generations. That is, the more than 246,600 pillars of spirits worshipped here are the souls of people who perish in the line of duty to defend their country" (参据のしお り) ${ }^{4}$.

\footnotetext{
${ }^{4}$ lbid.
}

SKHID Vol. 1 (2) May-June 2021 
This rhetoric is supported by the Shinto Policy Association (Shinto Seiji Renmei). The purpose of the Association is, in particular: "to establish a national ritual ( 国家儀礼 - "kokka girei") for the precious spirits worshipped in the Yasukuni Shrine - for the spirits of people who died defending Japan". At the same time, the Association is called to "dispel misunderstandings about Japanese historical facts and promote the morality of our esteemed nation as one that can contribute to peace in the world"5. Thus, the sanctuary itself and its supporting institutions have a policy of focusing on the heroism of the spirits of those who defended Japan to ensure a peaceful future. The fact that some participants in the war were convicted by an international tribunal as class-A war criminals are not mentioned in this rhetoric.

An attempt to smooth over the conflict over the Yasukuni-jinja is considered to be a request from 1978 by the rector of the temple of the Buddhist school Shingon ( 真言宗) Honzen-ji (本 禅寺), monk Nakata Junna (仲田順 和, 1934) to Pope Paul VI held a Mass for all the souls of the dead, who are worshipped in Yasukuni-jinja, as well as the souls of all those who died because of their actions (Breen, 2011). Pope John Paul II complied with this request in 1980, but it did not reduce the international community's criticism of the Yasukuni shrine.

Characteristically, Japanese apologists for the pilgrimage to the Yasukuni Shrine adhere to the assessment of Japan not as an aggressor, but as a victim of war. In particular, this position is taken by Japanese politician Fujio Masayuki (藤尾正行, 1917-2006), who equates the Japanese pilgrimage to Yasukuni-jinja to Chinese visits to Confucian temples and questions the legitimacy of assessing the killing of people in war as a crime (Breen, 2011). At the same time, it should be noted that this position contradicts the official course of Japanese policy.

The increase in anti-Japanese sentiment in Asia could be observed during 2014, i.e. after the visits of government officials to the Yasukuni Shrine. Especially famous was the statement of the Chinese ambassador to London, Liu Xiaoming (刘晓明， 1956, period as ambassador - 2010-2021), who compares the sanctuary of Yasukuni and a kind of Horcruxes, which represents "the darkest parts of the Japanese soul" (H.E. Ambassador ..., 2014, October 1). The main reason for the criticism and attention to the visits to the Yasukuni shrine by the country's authorities is the symbolic side of this action, in particular, the confirmation of the lack of recognition by Japan of its guilt for aggression in Asia. In these cases, it is the policy of the Japanese parliament towards the Yasukuni Shrine that is called an example and proof that militaristic sentiments and pan-Asian ambitions for leadership in Asia remain in Japan. In addition to the Yasukuni Jinja, similar discussions have arisen over Japanese history textbooks since the 1980s and about war museums and memorials located near the Yasukuni Shrine.

However, the current attitude towards the Yasukuni Shrine involves its evaluation as a religious institution (宗 教宝神 - "shu:kyo: ho:zin"), which exists for the conduct of

\footnotetext{
${ }^{5}$ (神政連が目指す国づくり) Shinseiren ga mezasu kunidzukuri. // Shintō seiji renmei. https://www.sinseiren.org/index.html. (In Japanese)
}

Shinto rites. Rites in honour of the spirits of "eirei" in this sense are understood as acts that have nothing to do with Japanese militarism. Instead, the symbolic meaning of both the pilgrimage and the functioning of the Yasukuni Shrine is seen in the core ideals of loyalty, self-sacrifice, and patriotism, which remain among the core national values. From this point of view, the fact of the existence and functioning of the Yasukuni Shrine testifies to the ambivalence not of the shrine itself, but of the Japanese attitude to Pan-Asianism, which remains a cornerstone of inter-Asian relations.

History textbooks are one of the main tools of forming a national memory of past events. Controversy over the specific wording of such textbooks began in the 1960s. The conservative position of the Japanese Ministry of Education in this period is characterized by a negative attitude towards the manifestations of leftist sentiments in the conduct of educational policy. Namely, the consolidation of leftist views, according to the political elite of the period, cannot lead to the formation of positive patriotism and national pride. Therefore, in recent history textbooks written and approved in the 1960s, we can see a softening of the wording and descriptions of Japan's actions in the Asian war. Thus, the "aggression" (侵略 "shinryaku") of Japan in northern China could be described as "advancement" (進出 - "shishutsu"), and the Korean independence movements were called "Korean disorders". The use of such formulations leads not only to an increase in anti-Japanese sentiment in Korea and China but also to criticism from the media, in particular from the well-known newspaper Asahi Shinbun (朝日新聞 ). Other controversial points are such episodes as the "Nanjing Incident" (南京 事件 - "Nanjing Jiken", in other languages - "Nanjing Massacre", 南京大屠杀), the problem of Korean "comfort women" - 慰安婦 - "lanfu") and others. cases when textbooks downplay the aggression of Japanese actions or war crimes. Thus, in the New History Textbook of 2005, in describing the events of the Pacific War, in describing Japan's actions, the emphasis is on Japan's efforts to protect Asian countries from the onset of the West (New History Textbook, 2005: 48-54). As a confirmation of the success of this policy, there is a quote from a speech by Malaysian politician Raja Nong Chika (1953): "Japanese soldiers supplanted the forces of Western Europe, which for many years colonized the peoples of Asia. They surprised us because we didn't think we could defeat white people, they inspired us. They woke us from our long sleep and convinced us that we could make the people of our ancestors ours again" (New History Textbook, 2005: 54). Discussions over history textbooks continue in modern Japan, along with the emergence of new publications. $\mathrm{S}$. Lawson calls the phenomenon of "post-war guilt" the reason for the controversy of such attitudes, which describes the situation of recovery by a certain community of recognition of the fact of a traumatic past (Lawson, 2011). In particular, the "Japanese nation" itself was called in this case a victim of the actions of the Japanese military authorities (it is important to emphasize the fact that even in this rhetoric there is no accusation against the emperor) (Conrad, 2010).

Analysing this case, the fact of social criticism of such positioning of Japanese hostilities should be noted. During the 1960s, along with the revival of Pan-Asianism at the level of international relations, there was a negative 
attitude towards Pan-Asian wartime rhetoric. Such sentiments were preceded by the formation of the Japanese constitution and the consolidation of pacifism as the main course of the new Japanese modernization. Within this course, Pan-Asianism was understood as the cause of the "Great East Asian War", which in turn led Japan not only to defeat in the war but also to the situations in Hiroshima (広島) and Nagasaki (長崎). together with the formation of a negative image among neighbouring countries (Kim, 2008). Attempts to correct the textbooks after 1982 and further work on them can be seen as a political step towards establishing diplomatic international relations.

Considering the peculiarities of the Japanese perception of the past, Kumakura Isao suggests that the central guideline for the development of the whole universe of Japanese culture is the aesthetic worldview. Focusing on aesthetics leads to a "hollow centre" in the perception of opposite objects (Kumakura, 1989). In practice, this means that when there are several opposing "forces" (which can be understood as conflicting points of view of any social, political or religious sphere), it is the "field centre" that assumes the role of a "buffer zone" that neutralizes the conflict. Another cornerstone of the Japanese consciousness, which is important for understanding the politics of memory in this country, the researcher considers the lack of focus on morality as a category of evaluation of actions (Esenbel, 2007). Instead, as Kumakura writes, Japanese culture is characterized by positioning the category of beauty as the highest measure of evaluation of any actions and processes.

From this point of view, reflection on one's past and its acceptance, as well as feelings of guilt, are not rational because they do not correspond to aesthetic categories. At the same time, the choice of a strategy of forgetting certain events of the historical past and refusing to reassess this past is understood as an act of preserving national identity. This theory explains not only the ambivalence of Japanese memory policy but also the duality in the assessment of Pan-Asianism as a cornerstone in shaping the discourse of Japanese history of the second half of the XIX-XX centuries.

An example of the politics of memory can be seen in the phenomenon of the formation of "multiple identities" in Japan when the country simultaneously supports the strategy of pacifism, the image of Japan as a victim of the United States and the West and recognition of aggression by the Japanese Empire against other Asian countries. We emphasize that these points of view continue to exist in modern Japan and the choice of a the particular position depends on the context and currents of view.

The possibility of the existence of relative or multiple truth is called an internal characteristic of Japanese culture, as well as an aesthetic-oriented system of values. Characteristically, the ecognition of the ineffectiveness of the application of the system of binary oppositions and clear criteria of individual truth leads us to understand the system of formation not only of Japanese Pan-Asianism but also of national identity in general. Thus, the formation of a unified strategy of memory policy within Japanese culture can be considered impossible from the point of view of it's internal logic.

\section{Conclusions}

Thus, the Pan-Asianism of the Meiji era is critically evaluated in the context of the modern discourse of constructing the politics of memory. At the same time, PanAsianism became the centre of discussions around the assessment of the role and place of Japan in the events in the Asian region in the first half of the XX century, which are called the "Great East Asian War". Against the background of Japan's official recognition of its aggression in Asia and the consolidation of pacifism as the main direction of future new modernization at the constitutional level, we can observe an ambivalent attitude to both PanAsianism itself and Japan's wars.

The presence of conservative and right-wing sentiments within the Japanese political and intellectual elite leads to the emergence of a nationalist vector for the development of Japanese memory policy. This forms the opposite attitude to the Sino-Japanese wars, in which Pan-Asian rhetoric is recognized as a strategy to justify Japanese aggression. The third vector of Japan's policy of remembrance involves the assessment of the Fifteen Years' War as the result of the actions of the Japanese military, which must admit its guilt not only to Asia but also to the Japanese nation.

Discussions surrounding the assessment of these events are held within the framework of contemporary Japanese political and socio-philosophical discourse. It is not so much the fact that Japan is waging wars and Japan's Asian identity that is being re-evaluated as the motives and position of Japan itself in these events. The ambivalence of the attitude to the events of the "Great East Asian War" and the impact of this attitude on the transformation of Japanese national identity can be illustrated by the situation around the Yasukuni Shrine, war memorials near the shrine and history textbooks that are the focus of international media. This shows the transformation not only of the Japanese politics of memory but also of the attitude to those Pan-Asian ideas that still govern the transformation of identity within the region.

\section{REFERENCES}

Bix, H.P. (2001). Hirohito and the Making of Modern Japan Harper Perennial. Harper Perennial. $832 \mathrm{p}$.

Breen, J. (2010). Popes, Bishops and War Criminals: reflections on Catholics and Yasukuni in post-war Japan. The AsiaPacific Journal, 8:9, 3. https://apijf.org/-John-Breen/3312/article.html

Conrad, S. (2010) Remembering Asia: History and Memory in Post-Cold War Japan. In: Assmann A., Conrad S. (eds) Memory in a Global Age. Palgrave Macmillan Memory Studies. Palgrave Macmillan, London. https://doi.org/10.1057/9780230283367 9

Deng, Y. (1997). Japan in APEC: The Problematic Leadership Role. Asian Survey, 37 (4) (April): 353-367.

Duus, P. (2001). The New Asianism. In: Arne Holzhausen. Can Japan Globalize? Studies on Japan's Changing Political Economy and the Process of Globalization in Honour of Sung-Jo Park. Heidelberg: Physica: 245-256.

Esenbel, S. (2007). The Legacy of the War and the World of Islam in Japanese Pan-Asianist Discourse: Wakabayashi Han's Kaikyō Sekai to Nihon, In: Rotem Kowner. Rethinking the Russo-Japanese War 1904-05. (Vol. 1. Centennial Perspectives). Folkestone: Global Oriental: 263-280.

Final Communique of The Asian-African Conference held in Bandung from 18th to 24th April, 1955. $10 \mathrm{p}$. https://bandungspirit.org//MG/pdf/anri-bandung conferencefinal communique.pdf 
Fretwell, L. (2016). What defined war memories in Japan during the postwar period and what impact did they have on Japan? Merici, 2: 69-76. http://press-files.anu.edu.au/downloads/press/n2328/pdf/ch08.pdf

H.E. Ambassador Liu Xiaoming's Article in the People's Daily: Militarism is Japan's "Voldemort" (2014, October 1). Embassy of the People's Republic of China in the United Kingdom of Great Britain and Northern Ireland. Embassy News. http://www.chinese-embassy.org.uk/eng/EmbassyNews/2014/t1130676.htm

Hashimoto, Akiko (2015). The Long Defeat: Cultural Trauma Memory, and Identity in Japan. New York: Oxford University Press. 208 p.

Hatoyama, Yukio. (2009, August 13). My Political Philosophy. Financial Times. https:///www.ft.com/int//cms/s/0/997045488800-11de-82e400144feabdc0.htm|\#axzz3qM8DswQl

Kapranov, S.V. (2015). Proekt Skhidnoaziyskoyi spilnotyi mistse Kytayu v niomu: yaponskyy pohlyad. Skhodoznavstvo, 70: 50-68 (In Ukrainian).

Kapranov, S.V. (2017). Kytay $v$ ideolohiyi yapons'koho panaziatyzmu. In: Kytay ochyma Aziyi. Kyiv: Instytut skhodoznavstva im. A. Yu. Krymskoho NAN Ukrayiny: 146217 (In Ukrainian).

Kim, Mikyoung. (2008). Pacifism or Peace Movement?: Hiroshima Memory Debates and Political Compromises. Journal Of International And Area Studies, 15(1): 61-78. https://s-space.snu.ac.kr/bitstream/10371/96462/1/5.Pacifism-or-Peace-Movement-Hiroshima-Memory-Debatesand-Political-Compromises-Mikyoung-Kim.pdf

Kumakura, Isao. (1989). Tea in Japan: Essays on the History of Chanoyu. University of Hawaii Press. 285 p.

Lawson, S. (2011). War memories and Japan's 'normalization' as an international actor: A critical analysis. European Journal of International Relations. 17(3): 405-428. https://doi.org/10.1177/1354066110365972

Mahathir, bin Mohamad. (1994). Regional Grouping in the Pacific Rim: An East Asian Perspective. In: The Future of The Pacific Rim: Scenarios for Regional Cooperation. Westport, Connecticut-London, pp. 50-68.

New History Textbook (2005). Chapter 4 \& 5. Tokyo: Fusosha. https://web.archive.org/web/20050906080746/http://www.tsuk urukai.com/05 rekisi text/rekishi English/English.pdf

Takenaka, A. (2015). Yasukuni Shrine: History, Memory and Japan's Unending Postwar. Honolulu: University of Hawai'i Press, and Studies of the Weatherhead East Asian Institute Series, Columbia University. 296 p.

Takenaka, A. (2016). Mobilizing Death: Bodies and Spirits of the Modern Japanese War Dead. Palgrave Macmillan, pp. 351363.

Tankha, B. (2003). Okakura Tenshin and Pan-Asianism: Shadows of the Past. Kent, UK: Global Oriental. $176 \mathrm{p}$.

\section{Олександра Бібік,}

Донеџький національний університет імені Василя Стуса (Вінниця, Украӥна)

e-mail: aleks.7.pad@gmail.com,ORCID 0000-0002-6610-852X

\section{ТРАНСФОРМАЦІї ЯПОНСЬКОї ПОЛІТИКИ ПАМ'ЯТІ II ПОЛОВИНИ XX - ХХІ СТ. В КОНТЕКСТІ ПАНАЗІЙСЬКИХ АМБІЦІЙ}

Статтю присвячено аналізу ролі паназіатизму в формуванні японської політки пам'яті в період після Другої Світової війни. Показано, що починаючи 3 періоду Мейдзі, в Японії закріплюється подвійне ставлення до «Азії»: з одного боку, як до регіону високої духовності та культури, з іншого боку, як до регіону, який є відсталим від Заходу або Європи в плані економічного, політичного та технологічного розвитку. В 1950-х рр., коли в Японії настає період економічної кризи, зумовленої, зокрема, поразкою у Другій Світовій війні, окупаційним режимом та процесами формування воєнної пам'яті, з боку японських інтелектуалів ми бачимо тенденції віднесення Японії до простору «Азії». Якщо за часів війни паназійська ідеологія використовувалася для виправлення імперської ідеології та колоніалізму, сучасні паназійські концепції тяжіють до створення союзу країн Південно-Східної Азії, з метою підтримки та взаємного розвитку. Подальший розвиток цих настроїв залежить від втілення існуючих проектів ASEAN та особливостей дії прийнятих політичних та економічних стратегій азійської співдружності.

У статті вперше проводиться комплексний аналіз тих конституційних документів, едіктів та промов японских політичних діячів, які показують трансформації японської політики пам'яті. Виділено основні терденції розвитку даної політики, які полягають в пацифічній спрямованості та поступовому формуванні нового азіанізму. Проаналізовано дискусії навколо святилища Ясукуні та японських підручників 3 історії як приклади втілення названих тенденцій японської політики.

За умови закріплення пацифічної позиції Японії на рівні конституції, існують консервативні та націоналістичні погляди на японську війну в Азії. У межах японської політики пам'яті паназіатизм сприяє розвитку амбівалентного ставлення до факту японської експансії в Азії. У межах консервативної позиції японська провина піддається сумніву. Помітні тенденції до проголошення необхідності визнання героями учасників війни, трактування «великої східно-азійської війни» як війни самооборони, визнання правильності та істинності паназійських ідеалів Японії доби Тайсьо та Сьова.

Ключові слова: паназіатизм, політика пам'яті, новий азіанізм, святилище Ясукуні.

(c) Oleksandra Bibik

Надійшла до редакції: 14.05.2021

Прийнята до друку: 22.06.2021 